OPEN ACCESS

Edited by:

J. B. Ruhl,

Vanderbilt University, United States

Reviewed by

Niko Soininen,

University of Eastern Finland, Finland

Barbara Cosens,

University of Idaho, United States

*Correspondence:

Michael C. Leach

m.c.leach@tilburguniversity.edu

Specialty section:

This article was submitted

to Social Physics,

a section of the journal

Frontiers in Physics

Received: 08 February 2021

Accepted: 24 May 2021

Published: 25 June 2021

Citation:

Leach MC (2021) Negotiating the Descriptive-Normative Frontier of

Complexity Research in the Anthropocene.

Front. Phys. 9:665727.

doi: 10.3389/fphy.2021.665727

\section{Negotiating the Descriptive- Normative Frontier of Complexity Research in the Anthropocene}

\author{
Michael C. Leach * \\ Tilburg Law School, Tilburg University, Tilburg, Netherlands
}

This mini-review article offers a commentary on a singular analytical problem faced by legal scholars who use complexity theory and methods in legal research on climate change and the "Anthropocene". It positions such research as a subset of complexity scholarship in law, which is generally faced with the methodological and analytical challenge of negotiating and reconciling empirical description with normative prescription. It argues that this challenge is particularly acute for legal scholars writing on climate change and the Anthropocene. Using examples from scholars writing about "Earth systems law," it demonstrates how a heavy reliance on complexity-based empirical data as a source material for normative claim-making can distract scholars from important but difficult questions about normative legitimacy and how legal change happens at multiple levels. The special epistemological challenges posed by climate change and the Anthropocene should demand that scholars writing in this domain be especially mindful and explicit on how they link complexity descriptions to the normative claims they make, both for the sake of scientific credibility as well as for the legitimacy and viability of their propositions.

Keywords: complexity, Anthropocence, law, climate change, methodology and approaches

\section{INTRODUCTION}

Climate change and the "Anthropocene" [1] pose new challenges for understanding how complexity can usefully contribute to research in environmental law as legal discussions increasingly anticipate existential challenges to law in the face of heightened risks in the uncertain future of a rapidly changing planet $[2,3]$. The advent of the Anthropocene has spawned calls for better and new understandings of humanity's relationship(s) to the planet along with considerable debate about how law should change in the future [4-6]. How complexity might contribute to these discussions is not self-evident. While it is uncontroversial that complexity-based analytical frameworks can provide insights into the dynamics of law's constitutive responsibility for both enabling and mitigating climate change, it is far less certain what normative contribution complexity models and analysis can or should make. This short article will focus attention on the boundary zone where the descriptive meets the normative in complexity studies in law to consider problems that arise when the two are not clearly distinguished in legal discussions about the Anthropocene. It will argue that muddying the descriptive and the normative leaves insufficient room for considerations about how law is to be socially legitimized as a part of any adaptive response to climate change. While there are opportunities for complexity research to serve as a frame of reference for law in the Anthropocene, its use comes with some dangers that demand the careful delineation of normative questions for which complexity on its own cannot be expected to provide answers. 


\section{COMPLEXITY'S NORMATIVITY FOR LEGAL RESEARCH}

Legal scholars have been imagining complexity's utility for law and legal analysis for at least the past quarter century. Initially, it was seen as a compelling antidote to the limitations of traditional, doctrinal legal analysis. One of its earlier advocates, JB Ruhl, envisioned complexity as a key to a better understanding of law and society interactions and hoped that complexity would be a way to break free from the descriptive limitations of "reductionist" legal reasoning and the increasingly complicated legal architecture that such reasoning misguidedly constructed in pursuit of "absolute system predictability" [7]. By analogizing law to a dynamic, interactive complex system, it became possible to describe in new ways for how and why law and legal phenomena change over time as outcomes of processes of systemic selfassembly and emergence, without having to rely on mechanistic and linear doctrinal or institutional explanations that often struggle to account for observable reality [8].

Ever since then, complexity theorists have offered new perspectives and vocabularies for understanding a variety of legal phenomena over the past decades, often demonstrating its novel utility for certain kinds of legal research. However, the application of complexity to law generally has never been clear-cut, and its utility has always been bounded by the difficulty of distinguishing and negotiating the relationship between its descriptive capacity with the normative concerns of law and legal reasoning. It is not clear, for instance, how to best describe law as a systemic object of complexity analysis: is law a system of interacting norms [9]; or an institutional administrative system governing complex societies [10]; or a site of interaction between norms and larger social or geophysical systems [11]; or something else? Describing law in complex terms as an evolving, nonlinear complex system that produces stochastic and probabilistic outcomes [12] can run against the grain of law's self-image as a stabilizing force that ensures future certainty in social relations or that anchors political-legal orders around goals and policy objectives in the legitimate exercise of authority [13]. Complexity's fit with law, in other words, is imperfect.

This imperfection can pose risks when certain realities are given normative readings when they are described as complex. As social and legal constructs [14], legal institutions and rule systems present thorny normative problems that complexity-based descriptions about law struggle to engage with. While there is little that is objectionable with using complexity to understand how normative goals are pursued in legal systems [15], the same cannot be said of deriving normative conclusions from complex descriptions of law or other empirical realities. Complexity-based proposals that legal systems should have as their goal system stability or robustness teeter on that line [16]. Propositions that legal systems benefit from being more "resilient," or by increasing their adaptative capacities by promoting lower level systemic innovation [7], etc., are unproblematic only when they do not presume to know what normative outcomes such as systemic features should produce. One cannot simply assume that any legal or legislative intervention that is inspired by complexity will be "good" or appropriate simply because it respects complex system dynamics [17]. Complexity does not lend itself easily to normative claim-making because it is not designed for that purpose [8].

This awkwardness of complexity's fit parallels rich ongoing debates about the fluid and difficult relationship between law and science generally, much of which tends to emphasize that they are distinct realms [18]. One can consider how legal systems in some ways maintain this distinction, such as with mechanisms like the precautionary principle in environmental law that recognizes the limits of scientific certainty in predicting future risks and serves as a counterweight to narrow science-based decision-making processes by experts [19]. On the other hand, Sheila Jasanoff has pointed out how legal scholarship typically has a "deep rooted commitment to the existence of objective facts" $[20,21]$ and Robin Feldman has cautioned against law and policymakers relying too heavily on science as an "authoritative other" whose "superior reliability allows us to indulge in the fantasy that it can reduce us from the discomfort of legal dilemmas and deliver the certainty we crave" [22]. "The appropriate role for science," Feldman argues, "should be to test the assumptions that underlie legal rules, rather than prescribe them" [22]. The inverse has also been argued that it is inappropriate for the law and courts to act as arbiters of scientific truth, and Katalin Sulyok has observed how international courts are grappling with this problem and increasingly ruling on the legitimacy of competing scientific evidentiary claims only from the restricted perspective of legal rules [23]. The ambiguity of this law/science divide becomes similarly problematic when complexity is used in legal scholarship and commentary about climate change and the Anthropocene. Even though the bread and butter of much complexity research is systemic uncertainty and nonlinearity, descriptions of largely positivist complex realities in legal scholarship can offer temptations of "superior reliability" and material certainties that can distract from the equally complex social and political structures, processes, and mechanisms by which law and norms are legitimized in the human society.

\section{COMPLEXITY IN ENVIRONMENTAL AND CLIMATE CHANGE LEGAL SCHOLARSHIP}

Environmental law has attracted the attention of complexity scholars since as early as the 1990s [24], in part because its relative incoherence [25] makes it fertile ground for complexity research: it is methodologically plural, interdisciplinary, and concerns itself with intricately interconnected legislative and treaty regimes that address difficult transboundary and multijurisdictional problems. Finding a home within this domain, scholars have turned to complexity as a theoretical frame to describe environmental governance regimes [26-28], to anticipate how law will change as social values and interests compete in the advent of climate change [29], and to critically reflect on law's present inadequacy at tackling the magnitude of environmental problems around the world [30, 31]. In arguing that international environmental law "exhibits some key characteristics of a complex adaptive system," Kim and Mackey, for instance, propose that in spite of its capacity for 
self-organization, international environmental law is mal- or misadaptive and needs to be "more appropriately align[ed] with the functioning of the Earth system itself" [32].

Legal scholars writing in the "Earth systems" domain are emblematic of a certain temptation in environmental law and complexity scholarship to intermingle the normative and the descriptive in writing about the climate change and the Anthropocene. The Earth systems approach treats the Earth as a single complex and dynamic system [33] that is characterized by a limited number of biochemical subsystems that human activity is pushing out of balance in ways that threaten the biosphere's capacity to maintain life [34,35]. The paradigm of "Earth system law" seeks out normative determinations about what coordinated human behavior would best manipulate the constitutive flows of energy and matte of those subsystems in ways that can maintain biospheric stability for human and nonhuman life. In this way, law should better "reflect" Earth system transformations and be "simultaneously reformative or prescriptive ... to proactively enable and govern human-dominated Earth-system transformations for sustainability" [30]. Such an approach implies that the structural benefits of normative centralization around the "Earth system" would be enough to legitimize the global normative project of "aligning with the functioning of the Earth system."

From a normative standpoint, the complexity-based description of the "Earth system" produces a powerful and unambiguous narrative that often reduces climate science down to specific reference points like "planetary boundaries" [36] or "tipping points" [37]. The presentation of these reference points as certainties places any normative objective other than optimizing planetary biochemical systems into stark relief as concerns of secondary importance, thereby attempting to limit the scope and range of political solutions that should be available to policymakers in the present [38]. While using environmental and biochemical complexity as a reference or base for lawmaking is rhetorically compelling, assuming that it can translate into a self-evident global legal project disregards the complexity of the political mechanisms by which human polities around the world determine what should be done, what constitutes acceptable risk, or what relationship science should have with those questions [19, 39]. It also disregards how choices made about how to empirically describe climate change as a particular kind of complex process itself produces specific normative framings that can conflict with those offered by different models. Consider, for instance, how historical accounts of the complex human processes responsible for global warming today might offer very different prescriptions for what can or should be done on the basis of retrospective responsibility and distributive compensatory justice compared to future-oriented Earth system perspectives that aim to adjust human behaviors in ways that manipulate planetary biochemical systems [40, 41].

Things like reparations or debts owed by those who have benefitted from industrialization to present and future generations who will suffer its consequences do not fit the specific focus of the Earth system model. Furthermore, the planetary scale of its abstractions are difficult to translate down to middle- or microlevels where policy and legal actors must engage in compromise and horse trading among the many conflicting norms, values, opinions, needs, and interests that come to bear around climate change in different societies. In this sense, while laudable, the ambition of devising a coherent global normative framework around a particular complexitybased model of the world understates the difficult problem of how law is legitimized while overstating the universality of the problem it addresses. The call for law to be "align(ed) with the functioning of the Earth system" equates to a call to reorder national legal and political priorities and processes through some kind of a global planetary regulatory goal-setting process. The powerful rhetorical emphasis that the model provides that this must be done overshadows questions about how and in what form it could be done, who would benefit or lose the most in so doing, and who or what could have sufficient authority and legitimacy to accomplish it in the absence of any genuinely self-aware "global" public [19, $42,43]$.

None of this is to say that Earth system models of climate change are wrong, nor that using them for legal and normative purposes is also wrong. Rather, the concern here is with the reliance on complexity-based descriptions to make normative prescriptions in ways that obscure the norm-making role that modelers and scholars play whenever they interpret a given empirical reality as "complex." It is quite artificial to separate such models from the equally complex sociopolitical contexts in which they are made and those to which they are expected to be applied. Victor Galaz has referred to this as the analytical challenge of "double complexity" [44], which scholars in the "socio-ecological systems" subfield have tried to reconcile in singular system frames, although with no consensus on how exactly to do this [45]. Scholars have also tried to delicately navigate this terrain by limiting themselves to asking questions on how law plays a facilitating or obfuscating role in processes of legal change and reform in the face of climate change, and evaluating whether or to what degree law contributes to or weakens the capacity of social and governance systems to adapt or be "resilient" (i.e., capable of absorbing disturbances without having to induce structural systemic changes) [46, 47]. Importantly, however, such perspectives cannot rely on the descriptive systemic frames they deploy to address difficult normative questions of whether or to what degree social and political change and/or stability and continuity are good or desirable in the first place [48]. Engagement along these lines will always have to circle back authorial choices about what is or is not desirable and beg bigger questions about who benefits or loses when a given legal system is made more or less "resilient" or "adaptive" [49,50], or what kind of "resilience," if any, is desirable for a given legal system [51], or what is worth keeping and preserving, and what can "we" afford to lose and change [52]? These are substantive and often deeply political questions that descriptive complexity models of planetary systems cannot provide answers to on their own, largely because they are not designed to account for how social factors like knowledge, power, agency, and conflict factor into how different human societies determine their normative pRefs. $[48,53]$. 


\section{RECONSIDERING COMPLEXITY'S USES FOR LEGAL SCHOLARSHIP IN THE ANTHROPOCENE}

The brief discussion above cautions against relying on complexity models of climate change to meaningfully prescribe legal decisionmaking because doing so can miss or deflect attention away from the normative dimensions of the social and political contexts in which lawmaking occurs. These concerns are augmented further by orders of magnitude if the vastness of the Anthropocene is appreciated as being a kind of "hyper-object" that may be beyond our powers to describe accurately [54]. In this light, the role of climate change system modelers then becomes one of authoritatively reducing the unimaginable to the (merely) complex but in ways that are normatively consequential and should be treated with care by legal scholars. While one should be skeptical of the ability of complexity analyses to provide specific normative answers to the Anthropocene, they can nevertheless play a significant role in improving what Timothy Clark has called "scalar literacy" around law and climate change [55] and to offer insights into the ranges of options and possibilities available for decision-makers to choose from. Furthermore, if the Anthropocene truly does lie beyond our descriptive capacities, then complexity may be more useful to help elucidate the limits of human knowledge [56] and to draw the attention of lawyers and politicians to difficult problems where normative choice-making is needed in the face of uncertainty [26]. In such a role, complexity's utility comes not from its ability to portray the world more accurately or with greater normative truth, but from how it can assist with thinking about conflicting and contradictory environmental and social phenomena that coexist on multiple levels and scales. Clark offers the global market for biofuels as an example, something that is simultaneously beneficial and destructive, depending on which overlapping narrative about emissions reductions and deforestation one ascribes to [55].

What complexity models cannot be relied upon to do on their own, however, is to speak to the normative dimensions of the empirical findings they generate. This is because what makes them useful and meaningful for law is determined not by the strength of their data, but by the nature of the socialized domains in which modelers and authors use them as interventions for

\section{REFERENCES}

1. Crutzen PJ. Geology of Mankind. Nature (2002) 415:23. doi:10.1038/415023a

2. Burdon PD. Ecological Law in the Anthropocene. Transnational Leg Theor (2020) 11(1-2):33. doi:10.1080/20414005.2020.1748483

3. Birrell K, and Matthews D. Laws for the Anthropocene: Orientations, Encounters, Imaginaries. L Critique (2020) 31:233-8. doi:10.1007/s10978020-09282-8

4. Latour B. Facing Gaia: Eight Lectures on the New Climatic Regime. Cambridge: Polity Press (2017).

5. Haraway DJ. Staying with the Trouble: Making Kin in the Chthulucene. Durham NC: Duke University Press (2016).

6. Biermann F, and Lövbrand E. Anthropocene Encounters: New Directions in Green Political Thinking. Cambridge: Cambridge University Press (2019). particular legal purposes [45]. Legal scholars interested in complexity therefore have an ethical responsibility to resist the temptation that the empirical strengths of their complexity models give them any special methodological ability or authority to better determine what is normatively appropriate or better for the society [57]. Taking complex social and environmental realities into account may better help policymakers, but it cannot guarantee that they will be more able to discern what is normatively desirable. Indeed, with their emphases on empirical uncertainty and contingent variability, they may actually make it harder for them.

Nothing in this article should be construed as proposing that complexity scholars should never make normative claims about law, of course. Rather, the point is that it would be inappropriate for them to use the complexity of environmental realities as a rationale for de-complexifying political choice-making in ways that disregard the equally complex realities of the human political society and legal systems through which such realities are made meaningful. In effect, this is a call to remember that law is a politicized realm, and that scholars who are interested in complexity-based understandings of law in the Anthropocene cannot afford to disregard how the normative-descriptive interface affects the scientific credibility of their analyses and the political legitimacy of their prescriptions.

\section{AUTHOR CONTRIBUTIONS}

ML is the sole author of this manuscript.

\section{FUNDING}

This research was conducted as a part of the "Constitutionalizing in the Anthropocene" Project at Tilburg Law School, Department of Public Law and Governance, funded through the "Sectorplan Social Sciences and Humanities" of the Ministry of Education, Culture and Science (Ministerie van Onderwijs, Cultuur en Wetenschaap) of the Government of The Netherlands. Funds for open access fees were provided by Tilburg Law School, Tilburg University.

7. Ruhl JB. Complexity Theory as a Paradigm for the Dynamical Law-AndSociety System: A Wake-Up Call for Legal Reductionism and the Modern Administrative State. Duke L J (1996) 45(5):849. doi:10.2307/1372975

8. Hornstein DT. Complexity Theory, Adaptation, and Administrative Law. Duke L J (2005) 54(4):913. doi:10.2307/40040504

9. Post DG, and Eisen MB. How Long Is the Coastline of the Law? Thoughts on the Fractal Nature of Legal Systems. J Leg Stud (2000) 29:545-84. doi:10.1086/ 468085

10. Leach M, Scoones I, and Stirling A. Governing Epidemics in an Age of Complexity: Narratives, Politics and Pathways to Sustainability. Glob Environ Change (2010) 20:369-77. doi:10.1016/j.gloenvcha.2009.11.008

11. Ebbesson J, and Hey E. Introduction: Where in Law Is Social-Ecological Resilience? Ecol Soc (2013) 18(3):24. doi:10.5751/es-05750-180325

12. Auyang SY. Foundations of Complex-System Theories. Cambridge: Cambridge University Press (1998). 
13. Ebbesson J. The Rule of Law in Governance of Complex Socio-Ecological Changes. Glob Environ Change (2010) 20(3):414-22. doi:10.1016/j.gloenvcha. 2009.10.009

14. Room G. Complexity, Power and Policy. In: P Cairney and R Geyer, editors. Handbook on Complexity and Public Policy. Cheltenham: Edward Elgar (2015).

15. Ruhl J, and Katz DM. Measuring, Monitoring, and Managing Legal Complexity. Iowa L Rev (2015-2016) 101:191.

16. Farber DA. Probabilities Behaving Badly: Complexity Theory and Environmental Uncertainty. U C Davis L Rev (2003-2004) 37:145.

17. Le QB, Seidl R, and Scholz RW. Feedback Loops and Types of Adaptation in the Modelling of Land-Use Decisions in an Agent-Based Simulation. Environ Model Softw (2012) 27-28:83-96. doi:10.1016/j.envsoft.2011.09.002

18. Jasanoff S. A Constitutional Moment: Science and Social Order at the Millenium. In: B Joerges and H Nowotny, editors. Social Studies of Sciences and Technology: Looking Back, Ahead. Dordrecht: Kluwer Academic Publishers (2003).

19. Peel J. Science and Risk Regulation in International Law. Cambridge: Cambridge University Press (2010).

20. Jasanoff S. The Eye of Everyman: Witnessing DNA in the Simpson Trial. Soc Stud Sci (1998) 28(5-6):713. doi:10.1177/030631298028005003

21. Jasanoff S. Science at the Bar: Law, Science, and Technology in America. New York: Oxford University Press (1995).

22. Feldman R. The Role of Science in Law. Abingdon: Oxford University Press (2009).

23. Sulyok K. Science and Judicial Reasoning: The Legitimacy of International Environmental Adjudication. Cambridge: Cambridge University Press (2021).

24. Ruhl J. Thinking of Environmental Law as a Complex Adaptive System: How to Clean up the Environment by Making a Mess of Environmental Law Houston Law Review. Houston Law Review (1997-1998) 34:933.

25. Fisher E, Lange B, Scotford E, and Carlarne C. Maturity and Methodology: Starting a Debate about Environmental Law Scholarship. J Environ L (2009) 21(2):213-50. doi:10.1093/jel/eqp012

26. J Norberg and G Gumming. Complexity Theory for a Sustainable Future. New York City: Columbia University Press (2008).

27. Rockström J, Steffen W, Noone K, Persson A, Chapin FS, Lambin EF, et al. A Safe Operating Space for Humanity. Nature (2009) 461(2):472-5. doi:10.1038/ 461472a

28. Craig RK. "Stationarity Is Dead" - Long Live Transformation: Five Principles for Climate Change Adaptation Law. Harv Environ L Rev (2010) 34(1):9.

29. Ruhl J. Climate Change Adaptation and the Structural Transformation of Environmental Law. Environ L (2010) 40:363.

30. Kotzé LJ, and Kim RE. Earth System Law: The Juridical Dimensions of Earth System Governance. Earth Syst Governance (2019) 1:100003. doi:10.1016/j.esg. 2019.100003

31. Young OR. Governing Complex Systems: Social Capital for the Anthropocene. Cambridge, MA: The MIT Press (2017).

32. Kim RE, and Mackey B. International Environmental Law as a Complex Adaptive System. Int Environ Agreements (2014) 14:5-24. doi:10.1007/s10784013-9225-2

33. Steffen W, Richardson K, Rockström J, Schellnhuber HJ, Dube OP, Dutreuil S, et al. The Emergence and Evolution of Earth System Science. Nat Rev Earth Environ (2020) 1:54-63. doi:10.1038/s43017-019-0005-6

34. Bridgewater P, Kim RE, and Bosselmann K. Ecological Integrity: A Relevant Concept for International Environmental Law in the Anthropocene? Yearb Int Environ L (2014) 25(1):61-78. doi:10.1093/yiel/yvv059

35. Petersmann M-C. Earth System Law and Sympoiesis: The Earth, its Subjects and the Law (Forthcoming 2021).

36. Biermann F. Planetary Boundaries and Earth System Governance: Exploring the Links. Ecol Econ (2012) 81:4-9. doi:10.1016/j.ecolecon.2012.02.016

37. Eisenhauer DC. Tipping Points in the Anthropocene: Crafting a Just and Sustainable Earth. J Extreme Events (2017) 4(1):1750004-1. doi:10.1142/ s234573761750004x
38. Kennedy D. Challenging Expert Rule: The Politics of Global Governance. Sydney L Rev (2005) 27:5.

39. Webb J. Law, Ethics, and Complexity: Complexity Theory \& (And) the Normative Construction of Law. Cleveland State L Rev (2004) 52(1 \& 2):227.

40. Bonneuil C, and Fressoz J-B. The Shock of the Anthropocene. London: Verso (2016).

41. Moore JW. Capitalism in the Web of Life: Ecology and the Accumulation of Capital. London: Verso (2015).

42. Zürn M. Global Governance and Legitimacy Problems. Government and Opposition (2004) 39(2):268. doi:10.1111/j.1477-7053.2004.00123.x

43. Esty DC. Good Governance at the Supranational Scale: Globalizing Administrative Law. Yale L J (2005-2006) 115:1490.

44. Galaz V. Double Complexity: Information Technology and Reconfigurations in Adaptive Governance. In: E Boyd and C Folke, editors. Adapting Institutions: Governance, Complexity and Social-Ecological Resilience. Cambridge: Cambridge University Press (2012).

45. Cumming GS. Spatial Resilience in Social-Ecological Systems. Heidelberg: Springer (2008).

46. B Cosens and LH Gunderson. Practical Panarchy for Adaptive Water Governance: Linking Law to Social-Ecological Resilience. Cham: Springer Nature (2018).

47. Holling CS, and Gunderson LH. Resilience and Adaptive Cycles. In: LH Gunderson and CS Holling, editors. Panarchy: Understanding Transformations in Human and Natural Systems. Washington D.C.: Island Press (2002).

48. Olsson L, Jerneck A, Thoren H, Persson J, and O’Byrne D. Why Resilience Is Unappealing to Social Science: Theoretical and Empirical Investigations of the Scientific Use of Resilience. Sci Adv (2015) 1(4):e1400217. doi:10.1126/sciadv. 1400217

49. Cote M, and Nightingale AJ. Resilience Thinking Meets Social Theory. Prog Hum Geogr (2012) 36(4):475-89. doi:10.1177/0309132511425708

50. Chandler D. Resilience and the End(s) of the Politics of Adaptation. Resilience (2019) 7(3):304-13. doi:10.1080/21693293.2019.1605660

51. Powell NS, Larsen RK, and van Bommel S. Meeting the "Anthropocene" in the Context of Intractability and Complexity: Infusing Resilience Narratives with Intersubjectivity. Resilience (2014) 2(3):135-50. doi:10.1080/21693293.2014. 948324

52. Duit A, Galaz V, Eckerberg K, and Ebbesson J. Governance, Complexity, and Resilience. Glob Environ Change (2010) 20(3):363-8. doi:10.1016/j.gloenvcha. 2010.04.006

53. Davidson DJ. The Applicability of the Concept of Resilience to Social Systems: Some Sources of Optimism and Nagging Doubts. Soc Nat Resour (2010) 23: 1135-49. doi:10.1080/08941921003652940

54. Morton T. Hyperobjects: Philosophy and Ecology after the End of the World. Minneapolis: University of Minnesota Press (2013).

55. Clark T. The Value of Ecocriticism. Cambridge: University of Cambridge Press (2019).

56. Smil V. The Earth's Biosphere: Evolution, Dynamics, and Change. 2nd edn. Cambridge MA: MIT Press (2003).

57. Cilliers P. Complexity, Ethics and Justice. In: R Preiser, Editor. Paul Cilliers Critical Complexity: Collected Essays. Berlin: Walter de Gruyter GmbH (2016).

Conflict of Interest: The author declares that the research was conducted in the absence of any commercial or financial relationships that could be construed as a potential conflict of interest.

Copyright $\odot 2021$ Leach. This is an open-access article distributed under the terms of the Creative Commons Attribution License (CC BY). The use, distribution or reproduction in other forums is permitted, provided the original author(s) and the copyright owner(s) are credited and that the original publication in this journal is cited, in accordance with accepted academic practice. No use, distribution or reproduction is permitted which does not comply with these terms. 